\title{
A Structural Equation Model of Transformational Leadership for Industrial in Thailand
}

\author{
Yingyote Chokchaiworarat ${ }^{1} \&$ Krit Jarinto ${ }^{1}$ \\ ${ }^{1}$ Graduate School of Commerce Burapha University, Thailand \\ Correspondence: Yingyote Chokchaiworarat, Graduate School of Commerce Burapha University, Thailand. Tel: \\ 66-038-394-900. E-mail: iam_yingyote@ hotmail.com
}

Received: March 3, 2014

Accepted: March 26, 2014

Online Publication: May 27, 2014

doi: 10.5539/ibr.v7n6p97

URL: http://dx.doi.org/10.5539/ibr.v7n6p97

\begin{abstract}
This study attempted to investigate and search for the appropriate structure model of leadership in industrial organization of Thailand by comparison between leadership of two industry groups. The study relied on the data collected from 338 managers in Group awarded TQA / TQC (Thailand Quality Award / Thailand Quality Class) and Survival industries group according to the classification of the NESDB (Office of the National Economics and Social Development Board). A questionnaire 5 scale was used to collect the data which was analyzed using AMOS program v.18.0, the total response rate is $97.04 \%$. The study revealed that there is significant different of leadership between groups. Furthermore, the results light out that the transformational leadership is positively influenced with organization performance especially finance area. In the same line, transformational leadership is found to be not only positively effected with organization commitment but also as stronger effect on empowerment factor. The finding also shows the indirect effect between transformational leadership and organization performance via mediating factors. With believing of different leadership level and its effect, future study can be conducted in different research context. This research has figured out the weakness of empirical study in organization management literatures by connecting the leadership behavior, empowerment, and how they are associated to employee commitment to increase organization performance. In the same way, it has provided a guideline for the public sectors in general and particularly in industrial context on how to successfully implement change phenomena as well as how to get effective and efficient leadership with change management.
\end{abstract}

Keywords: transformational leadership, structural equation model, industrial leadership

\section{Introduction}

In competitive environment of industry in Thailand has changed in area of social, political and economic conditions rapidly cause the organization to learn and adapt to keep up with flow of such changes to survival, maintain its excellence and sustainability (Drucker, 1985). This change will have a greater impact as Thailand prepares to access ASEAN Economic Community make the executive industry must adapt to reflect the competitive environment more open. According to the final report from a consultant hired to analyze the development of manpower as Thailand strengthening of government policy (Faculty of Economics: Chulalongkorn University, 2010) has divided industry of Thailand into three major groups include the agriculture sector, production sector and services sector. The focus group of this research is production sector that Thai's government recommended to increase the competitiveness of industrial sector to more strengthened. According to the report of industry trends in Thailand which issued by Office of the National Economics and Social Development Board (NESDB, 2006) have determined capacity of Thai's industry and classified those industries from threshold attractive in a business context and ability to compete of manufacturer divided into three main groups as (1) Survival industries group (2) Improving industries group and (3) Potential industries group (see Table 1). The Survival industries group is targeted in the dissemination of knowledge to enhance competitiveness to meet the conditions change. 
Table 1. Classification of industry from threshold attractive in a business context and ability in Thailand

\begin{tabular}{lll}
\hline Survival Industries & Improving Industries & Potential Industries \\
\hline Industrial Machinery industry & Furniture industry & Automotive Industry \\
Steel industry & Beverage Industry & Petrochemical and plastic industry \\
Ship, rail and aircraft parts industry & Pharmaceutical industry & Chemical Industry \\
Metals Industry & Fashion textiles industry & Electronics industry \\
Paper Industry & Electrical industry & Rubber industry \\
Tobacco industry & Home appliances and office industry & Iron and steel industry \\
Dairy Industry & Rice Industry & Fish and canned seafood industry \\
Animal feed industry & Sugar Industry & Fruit and vegetable processing industry \\
& Meat and Poultry Industry & \\
\hline
\end{tabular}

Sources: (NESDB, 2006).

Research say the ASEAN Economic Community that Thailand as a member today, even if it would benefit the country in many ways, but they would not deny that on the other side effected in business and industry and has a rivalry with neighboring countries as also membership of the AEC higher as well. So, when consider the potential of the country that Thailand should be able to compete with neighboring countries and become a leader in this region in the future (Arthi, 2011). Organization need to adapt to a competitive advantage which an executive must create new ideas to support organization's strategy (Hitt, Ireland, \& Hoskisson, 2005). There are 2 main factors that make a significant strategic management of organizations with flexibility and match to environment 1) organization leadership development and 2) the vision of the organization which both of them shall be in the same direction and must have ability to deal with organization transformation. (Zaccaro \& Banks, (2004 Leadership plays a role in organization to turn a vision into reality with strategic driver for the organization and management of change in organizations, such as review of organizational strategic, structure and policies included create organization's culture, resources mobilization and continues to inspire everyone to involved in ownership (Allio, 2005; Fechter \& Horowitz, 1991; Nanus, 1992).

\section{Literature Review}

\subsection{Transformational Leadership}

Based on concept of Bass and Riggio (2006) provided meaning of Transformational Leadership as a people who provide attendees inspired to transcend their own interests for the interests of the organization as a whole is primary and who is the subordinate acts can be driven organizations to achieve beyond expectations. The four factors of transformational leadership (4 I's) (Bass \& Riggio, 2006) are discussed 1) Idealized influence describes leaders who are exemplary role models for associates. Leaders with idealized influence can be trusted and respected by associates to make good decisions for the organization. As idealized influence reflects the behavioral and the attributional aspects on the part of the followers, this style is divided into 2 subdimensions idealized influence attributed (ia) and idealized influence behavioral (ib) 2) Individualized consideration (ic) the degree to which the leader attends to each follower's needs, acts as a mentor or a coach to the follower and listens to the follower's concerns and needs. 3) Inspirational motivation (im) the degree to which the leader articulates a vision that is appealing and inspiring to followers. 4) Intellectual stimulation (is) the degree to which leader challenges assumptions, takes risks and solicits followers' ideas.

\subsection{Causal and Effect Factors of Transformation Leadership}

The causal and effect factors of Transformation leadership in this research comprises of 1) Emotional Intelligence or Emotional Quotient according to Goleman (2000) concept refers to the behavioral expression of organizational management demonstrating ability to recognize the feelings, thoughts and emotions of themselves and others and inspire himself to stimulate the mind as well as to meet the needs expressed their thoughts and their actions were reasonable (Goleman, 2000). The five factors of Emotional Quotient classified by Bar-On (2000) are Intrapersonal, Interpersonal, Adaptation, Stress management and General mood (Bar-On \& Parker, 2000). 2) Organization commitment, the three component model of commitment developed by Meyer and Allen (2007) arguably dominates organizational commitment research. This model proposes that organizational commitment is experienced by the employee as three simultaneous mindsets encompassing affective, normative, and continuance organizational commitment (Meyer \& Allen, 2007). 3) Empowering organizations, the psychological empowerment refers to a set of psychological states that are necessary for individuals to feel a 
sense of control in relation to their work. Rather than focusing on managerial practices that share power with employees at all levels, the psychological perspective is focused on how employees experience their work. This perspective is consist Meaning, Competence, Self determination and Impact (Spreitzer \& Quinn, 2001) 4) Organization performance, the Balanced Scorecard was introduced by Kaplan and Norton. The concept of the balanced scorecard enables organizations to achieve an integrated and aligned balanced focus between these four perspectives consist of financial, customer, internal processes and learning and growth, which collectively underpin the achievement of the organization's vision (Kaplan \& Norton, 1996). Finally, 5) Team effectiveness, Hackman and Wageman (2005) propose a new model of team effectiveness measurement using three-dimensional as following: Productive, Group Experience and Social Processes (Hackman \& Wageman, 2005).

\subsection{Purpose and Hypothesis}

The purpose of this research was to study causal and effect factors of Transformational leadership between 2 groups of sample and determine the Confirmatory Factor Analysis (CFA) in measurement model with Path Analysis of Structural Equation Modeling. As above discussed, that lead to developed conceptual framework and hypotheses as following:

H1. The level of Transformational leadership, causal and effect factors between Group awarded TQA /TQC and Survival industries group are different.

H2. The latent variables within Structural Equation Modeling have positive influence.

\section{Methodology}

\subsection{Sample Size}

The population of the study was the manager in 2 groups of Thailand's industrial sector. The $1^{\text {st }}$ group is Group awarded TQA / TQC consists of 12 types of industry and $2^{\text {nd }}$ group is Survival industries group consists of 8 types of industry. Based on The Generic Value chain activities (Porter \& Kramer, 2006) that create value for the entire 9 activities but due to several size of industry in sample group, researcher have provided clear elaboration and stated the population size is 5 managers per factory of industrial category that entrepreneurs should have at least possible. Determination sample size for each groups by using the sample size formula (finite population).

$$
n_{0}=[n /(1+n / N)]
$$

In the difference proportions of industrial category, researchers calculated the number of samples to ensure that selection of sampling factory covers all industries (Table 2-3). The total sample size is 338 which have been used in this study. The responded rate was $97.04 \%$ and 328 questionnaire collected back which used for further analysis.

$$
\text { Number of samples }=\frac{\text { Number of factory }(\text { a) } x \text { Quota per group }(\text { sample size calculation with no pilot study) }(b)}{\text { Total factory in sample group }(c)}
$$

Table 2. Category of group awarded TQA/TQC (Office of Thailand quality award, 2013)

\begin{tabular}{llcl}
\hline & Industrial category & number of factory (a) & number of samples (persons) \\
\hline 1 & Petrochemical industry & 8 & $=39$ \\
2 & paper Industry & 1 & $=5$ \\
3 & Auto parts industry & 2 & $=9$ \\
4 & Packaging industry & 1 & $=5$ \\
5 & Retail Industry & 2 & $=9$ \\
6 & Construction materials industry & 2 & $=9$ \\
7 & Electronics industry & 1 & $=5$ \\
8 & Natural gas industry & 2 & $=9$ \\
9 & Publishing Industry & 1 & $=5$ \\
10 & Food Industry & 5 & $=24$ \\
11 & Synthetic fiber industry & 1 & $=5$ \\
12 & Animal feed industry & 2 & $=9$ \\
\hline \multicolumn{2}{l}{ Total } & $28(\mathrm{c})$ & $133(\mathrm{~b})$ \\
\hline
\end{tabular}


Table 3. Category of survival industries group

\begin{tabular}{llcc}
\hline & Industrial category & number of factory (a) & number of samples (persons) \\
\hline 1 & Industrial Machinery industry & 11 & $=26$ \\
2 & Steel industry & 31 & $=72$ \\
3 & Ship, rail and aircraft parts industry & 3 & $=75$ \\
4 & Metals Industry & 32 & $=12$ \\
5 & Paper Industry & 5 & $=2$ \\
6 & Tobacco industry & 1 & $=4$ \\
7 & Dairy Industry & 2 & $=7$ \\
8 & Animal feed industry & 3 & 205 (b) \\
\hline
\end{tabular}

\subsection{Sampling Procedure}

Stratified random sampling and convenience random sampling technique was used in this study. The questionnaires were distributed hand to hand to the target managers in the organization who had easy access to the respondents. The completed questionnaires were handed directly back to the authors by research volunteer.

\subsection{Measurement}

The survey was developed based on previous studies, which comprises three main parts in the design of the questionnaire. The first part of the questionnaire allows the researcher to identify whether the respondent is eligible to take part in this research (screening questions); the second part of the questionnaire elaborated the Transformation leadership behavior; and the third part of the questionnaire elaborated the causal and effect variables that would be tested in the survey. In measuring the constructs, five-point Likert scale anchored by: "strongly disagree" (1) to "strongly agree" (5). Cronbach's Alphas of the measures were all comfortably above the lower limit of acceptability ( $\alpha>70)$, hence, all the measures were highly reliable.

\subsection{Data Analysis}

This study conducted data analysis and hypotheses testing using several statistical tools and methods which employed from SPSS software, which include Descriptive statistics (frequency, means, standard deviations, reliability, and inter correlations) and Inferential statistics (t-test). AMOS v.18 was used to achieve the objective with testing the hypothesis of Structural Equation Modeling (SEM) and Confirmatory Factor Analysis (CFA) analyses to test the goodness of fit test and Path analysis.

\section{Results}

\subsection{Compare Means of Transformational Leadership and Causal Factors}

Table 5 presents the summary mean values of causal and effect factors of Transformational leadership between 2 sample group. The results indicated that compare mean value was a significant ( $\mathrm{p}$-value<0.05) in Transformational leadership variable and almost entirely of causal and effect factors except area of Empowerment (p-value>0.05). The interpretation of the findings explains that different levels of Transformational leadership in both sample groups and Group awarded TQA / TQC higher than Survival industries group. Not only of Transformational leadership level but also Emotional intelligence, Organization commitment, Team effectiveness and Organization performance in both sample groups are different, which Group awarded TQA / TQC higher than Survival industries group as well. While almost entirely factors were different, the area of Empowerment is not significant. It can conclude that Empowerment factor of both groups are similar. 
Table 5. Means, standard deviations and t-test compare between 2 groups

\begin{tabular}{|c|c|c|c|c|c|c|}
\hline Transformational leadership & Industrial Group & $\mathrm{n}$ & Mean & SD & $\mathrm{t}$ & p-value \\
\hline \multirow{2}{*}{ TLS } & TQA/TQC & 130 & 4.01 & 0.23 & \multirow{2}{*}{5.88} & \multirow{2}{*}{$0.000 * *$} \\
\hline & SURv & 198 & 3.83 & 0.28 & & \\
\hline \multicolumn{7}{|l|}{ Causal and Effect factors } \\
\hline \multirow{2}{*}{ EIQ } & TQA/TQC & 130 & 4.10 & 0.16 & \multirow{2}{*}{10.93} & \multirow{2}{*}{$0.000 * *$} \\
\hline & SURv & 198 & 3.85 & 0.25 & & \\
\hline \multirow{2}{*}{$\mathrm{COM}$} & TQA/TQC & 130 & 4.10 & 0.23 & \multirow{2}{*}{5.36} & \multirow{2}{*}{$0.000 * *$} \\
\hline & SURv & 198 & 3.94 & 0.30 & & \\
\hline \multirow{2}{*}{ EMP } & TQA/TQC & 130 & 4.02 & 0.25 & \multirow{2}{*}{0.91} & \multirow{2}{*}{0.364} \\
\hline & SURv & 198 & 3.99 & 0.27 & & \\
\hline \multirow{2}{*}{ TEF } & TQA/TQC & 130 & 3.85 & 0.45 & \multirow{2}{*}{5.77} & \multirow{2}{*}{$0.000 * *$} \\
\hline & SURv & 198 & 3.52 & 0.52 & & \\
\hline \multirow{2}{*}{ BSC } & TQA/TQC & 130 & 4.10 & 0.24 & \multirow{2}{*}{10.82} & \multirow{2}{*}{$0.000 * *$} \\
\hline & SURv & 198 & 3.93 & 0.36 & & \\
\hline
\end{tabular}

Note. $*$ p-value $<0.05, * *$ p-value $<0.01$.

\subsection{Testing of Confirmatory Factor Analysis (CFA)}

Abbreviations used instead of variables

$\begin{array}{llll}\text { EIQ } & \text { :Emotional Intelligence or Emotional Quotient } & \mathrm{NC} & : \text { Normative commitment } \\ \text { SA } & : \text { Intrapersonal } & \text { EMP } & : \text { Empowerment } \\ \text { SS } & : \text { Interpersonal } & \text { MN } & : \text { Meaning } \\ \text { AD } & : \text { Adaptation } & \text { CP } & : \text { Competence } \\ \text { ST } & : \text { Stress management } & \text { SD } & : \text { Self determination } \\ \text { GM } & : \text { General mood } & \text { IP } & : \text { Impact } \\ \text { TLS } & : \text { Transformational leadership } & \text { BSC } & : \text { Balanced scorecard } \\ \text { IB } & : \text { Idealized influence Behavior } & \text { FI } & : \text { Financial } \\ \text { IM } & : \text { Inspiration motivation } & \text { CM } & : \text { Customer } \\ \text { IS } & : \text { Intellectual Stimulation } & \text { PC } & : \text { Internal Process } \\ \text { IC } & : \text { Individualized Consideration } & \text { LG } & : \text { Learning and Growth } \\ \text { COM } & : \text { Organization commitment } & \text { TEF } & : \text { Team effectiveness } \\ \text { AC } & : \text { Affective commitment } & \text { PD } & : \text { Productive } \\ \text { CC } & : \text { Continuance commitment } & \text { EX } & : \text { Group Experience } \\ & & \text { SC } & : \text { Social Processes }\end{array}$

Table 6. Model fit indicator (after computes Modification Indices: MI)

\begin{tabular}{cccccccccc}
\hline Model fit indicator & $\mathbf{R}^{2}$ & $\chi^{2} / d f$ & GFI & NFI & RFI & IFI & TLI & CFI & RMSEA \\
\hline Group awarded TQA / TQC & 0.806 & 1.281 & 0.900 & 0.946 & 0.920 & 0.988 & 0.981 & 0.987 & 0.047 \\
Survival industries group (SURv) & 0.560 & 2.035 & 0.901 & 0.946 & 0.925 & 0.972 & 0.960 & 0.972 & 0.072 \\
\hline
\end{tabular}




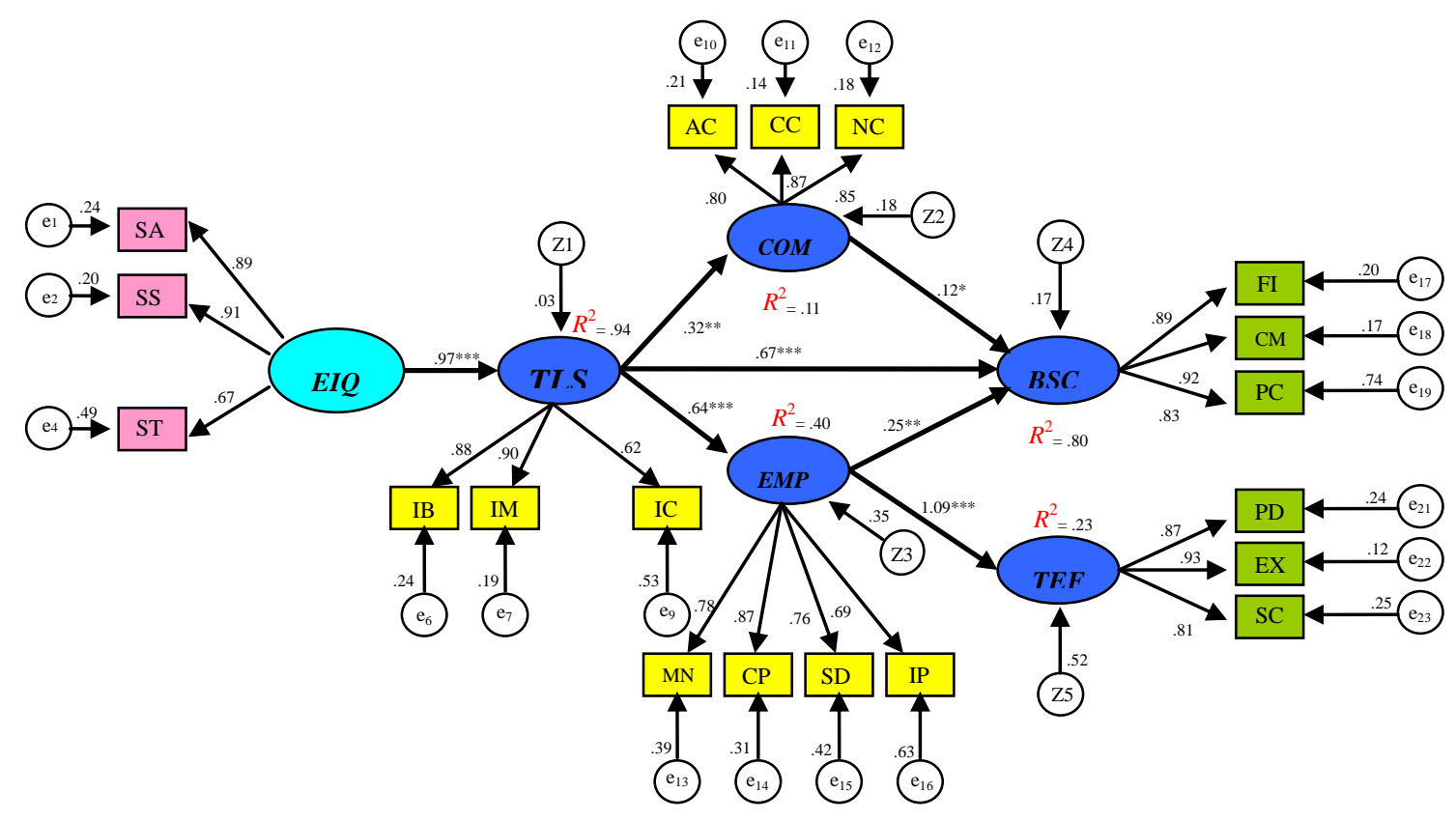

Group awarded TQA / TQC

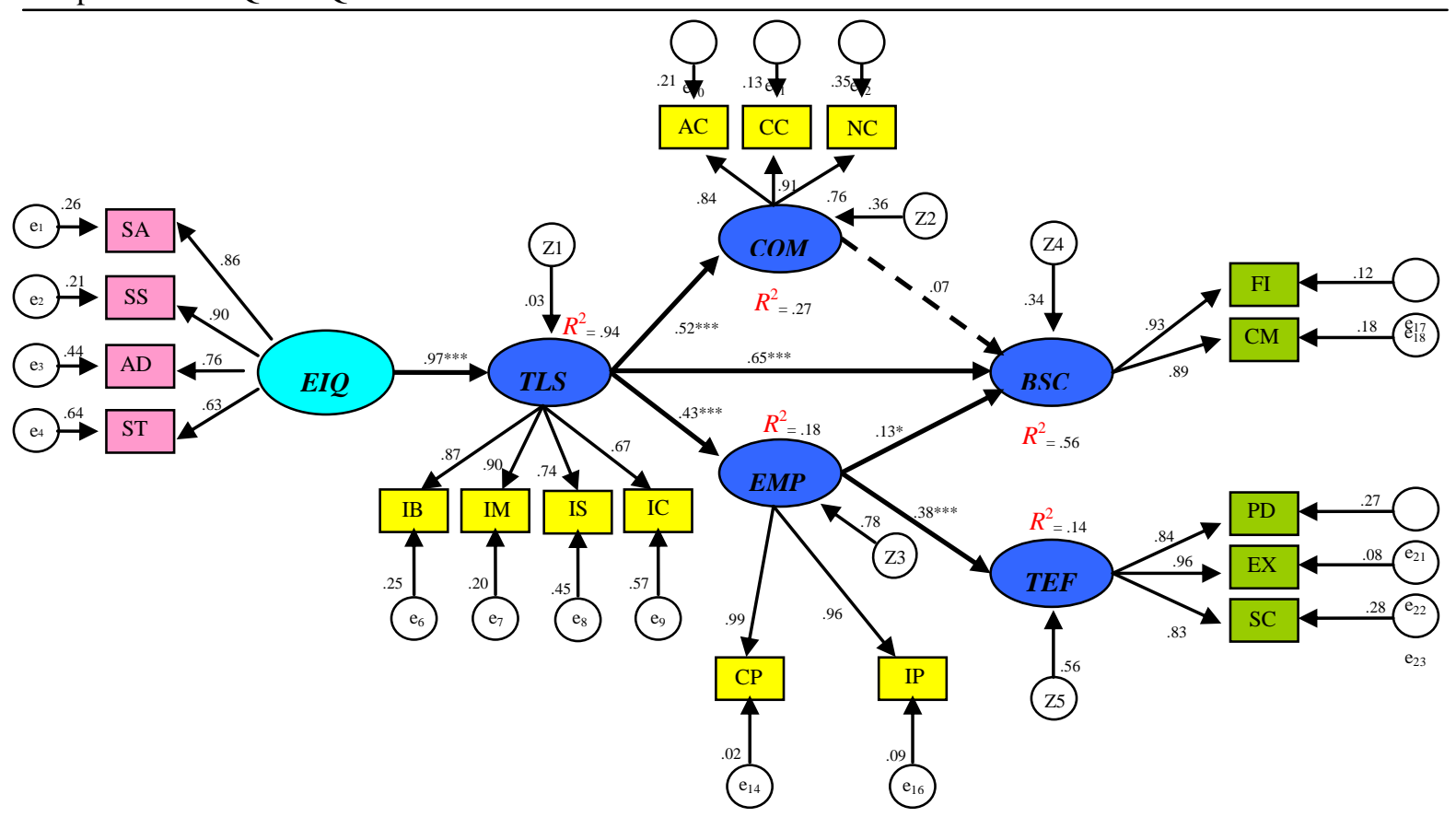

Survival industries group (SURv)

Figure 1. Strucral equation model of transformational leadership after computes Modification Indices: MI Notes: significant influence - - - - - non-significant influence

$* p<.05, * * p<.01, * * * p<.001$.

Table 6 contains fit indices for the proposed both models based on a maximum likelihood CFA analysis of the covariance matrix for the six latent variables. The Chi-Square / Degree of Freedom $\left(\chi^{2} / d f\right)$ for the two model less than the recommended value of 5 (Loo \& Thorpe, 2000); the GFI, NFI, RFI, IFI, TLI and CFI for both models exceeded the recommended value of 0.9 (J. F. Hair, et al., 2006). The RMSEA for the both models were less than the recommended value of 0.08 (Browne \& Cudeck, 1993). It can be conclude that, the analysis using modification indices of both models had a good fit from a practical standpoint. These fit indices were higher than the corresponding fit indices with empirical data. 
Figure 1 shows the structural equation model of Transformational leadership after computes modification Indices (MI) for each group. The results indicated that there was a significant and positive influence between the transformational leadership and causal / effect variable except influence between Commitment and Organization performance (BSC) of Survival industries group that showed non-significant. The results also showed that observed variables with the highest valuable elements (factor loading) in each latent variable of Group awarded TQA / TQC were 1) Interpersonal (SS) $(\lambda=0.91) 2)$ Inspiration motivation(IM) $(\lambda=0.90) 3)$ Continuance commitment (CC) $(\lambda=0.87)$ 4) Competence(CP) $(\lambda=0.87)$ 5) Group Experience (EX) $(\lambda=0.93)$ and 6$)$ Customer $(\mathrm{CM})(\lambda=0.92)$. In addition, the observed variables with the highest valuable elements (factor loading) in each latent variable of Survival industries group (SURv) indicated as 1) Interpersonal (SS) $(\lambda=0.90) 2$ ) Inspiration motivation(IM) $(\lambda=0.90) 3)$ Continuance commitment (CC) $(\lambda=0.91) 4)$ Competence $(\mathrm{CP})(\lambda=0.99)$ 5) Group Experience (EX) $(\lambda=0.96)$ and 6) Financial(FI) $(\lambda=0.93)$.

\subsection{Testing of Structural Equation Modeling (SEM) and Path Analysis}

Table 7. Summary of hypotheses testing (SEM)

\begin{tabular}{|c|c|c|c|c|c|c|c|c|c|c|c|}
\hline \multirow[t]{2}{*}{ No. } & \multirow{2}{*}{$\begin{array}{c}\text { Research } \\
\text { Hypotheses }\end{array}$} & \multicolumn{2}{|c|}{$\begin{array}{c}\text { Regression coefficients } \\
\text { (Unstandardized) }\end{array}$} & \multicolumn{2}{|c|}{ S.E. } & \multicolumn{2}{|c|}{ C.R. } & \multicolumn{2}{|c|}{ p-value } & \multicolumn{2}{|c|}{ Results } \\
\hline & & TQA & SURv & TQA & SURv & TQA & SURv & TQA & SURv & TQA & SURv \\
\hline 1. & $\rightarrow \mathrm{TLS}$ & 0.891 & 0.754 & 0.063 & 0.073 & 14.133 & 10.265 & $* * *$ & $* * *$ & Accept & Accept \\
\hline 2. & $\rightarrow \mathrm{COM}$ & 0.441 & 0.538 & 0.138 & 0.092 & 3.197 & 5.852 & $* * *$ & $* * *$ & Accept & Accept \\
\hline 3. & $\rightarrow \mathrm{EMP}$ & 0.860 & 0.615 & 0.163 & 0.114 & 5.273 & 5.410 & $* * *$ & $* * *$ & Accept & Accept \\
\hline 4. & EMP $\rightarrow$ TEF & 1.176 & 0.315 & 0.198 & 0.061 & 5.940 & 5.181 & $* * *$ & $* * *$ & Accept & Accept \\
\hline 5. & $\mathrm{COM} \rightarrow \mathrm{BSC}$ & 0.130 & 0.090 & 0.060 & 0.085 & 2.152 & 1.060 & $*$ & 0.289 & Accept & Reject \\
\hline 6. & $\mathrm{EMP} \rightarrow \mathrm{BSC}$ & 0.274 & 0.114 & 0.089 & 0.057 & 3.088 & 1.987 & $* *$ & $*$ & Accept & Accept \\
\hline 7. & $\mathrm{TLS} \rightarrow \mathrm{BSC}$ & 0.986 & 0.841 & 0.156 & 0.119 & 6.325 & 7.085 & $* * *$ & $* * *$ & Accept & Accept \\
\hline
\end{tabular}

Note. $* p<.05, * * p<.01, * * * p<.001$.

Table 7 presents the summary of research hypotheses between exogenous and endogenous variables that identified for each group. In general, the table shows that there were significant (p-value $<0.05$ ) and positive influences between a couple of hypothesis except factor of Commitment and Organization performance (BSC) of Survival industries group that hypothesis was rejected ( $\mathrm{p}$-value $>0.05$ ), which mean the employee commitment in Survival industries group does not influences to organization performance.

Table 8. Summary of direct, indirect and total effect (path analysis)

\begin{tabular}{|c|c|c|c|c|c|c|c|c|c|c|c|}
\hline \multirow{3}{*}{$\begin{array}{c}\text { Exogenous } \\
\text { variables } \\
\text { (x) }\end{array}$} & \multirow{3}{*}{ Effect } & \multicolumn{10}{|c|}{ Endogenous variables $-\mathrm{y} \quad$ (Standardized $)$} \\
\hline & & \multicolumn{2}{|c|}{$\begin{array}{l}\text { Transformational } \\
\text { leadership (TLS) }\end{array}$} & \multicolumn{3}{|c|}{$\begin{array}{c}\text { Organization } \\
\text { commitment }(\mathrm{COM})\end{array}$} & \multirow{2}{*}{$\begin{array}{c}\text { Empowerment } \\
\text { (EMP) } \\
\text { SURv }\end{array}$} & \multicolumn{2}{|c|}{$\begin{array}{c}\text { Team effectiveness } \\
\text { (TEF) }\end{array}$} & \multicolumn{2}{|c|}{$\begin{array}{c}\text { Organization } \\
\text { performance (BSC) }\end{array}$} \\
\hline & & $\begin{array}{l}\text { TQA/ } \\
\text { TQC }\end{array}$ & SURv & $\begin{array}{l}\text { TQA/ } \\
\text { TQC }\end{array}$ & SURv & $\begin{array}{l}\text { TQA/ } \\
\text { TQC }\end{array}$ & & $\begin{array}{l}\text { TQA/ } \\
\text { TQC }\end{array}$ & SURv & $\begin{array}{l}\text { TQA/ } \\
\text { TQC }\end{array}$ & SURv \\
\hline Emotional & $\mathrm{DE}$ & $0.968^{* * * *}$ & $0.971^{* * *}$ & 0 & 0 & 0 & 0 & 0 & 0 & 0 & 0 \\
\hline Intelligence or & IE & 0 & 0 & 0 & 0 & 0 & 0 & 0 & 0 & 0 & 0 \\
\hline Quotient & $\mathrm{TE}$ & 0.968 & 0.971 & 0 & 0 & 0 & 0 & 0 & 0 & 0 & 0 \\
\hline \multirow{3}{*}{$\begin{array}{l}\text { Organization } \\
\text { commitment }\end{array}$} & $\mathrm{DE}$ & 0 & 0 & 0 & 0 & 0 & 0 & 0 & 0 & $0.119 *$ & 0.072 \\
\hline & $\mathrm{IE}$ & 0 & 0 & 0 & 0 & 0 & 0 & 0 & 0 & 0 & 0 \\
\hline & $\mathrm{TE}$ & 0 & 0 & 0 & 0 & 0 & 0 & 0 & 0 & 0.119 & 0.072 \\
\hline \multirow{3}{*}{ Empowerment } & $\mathrm{DE}$ & 0 & 0 & 0 & 0 & 0 & 0 & $1.093 * * *$ & $0.380^{* * *}$ & $0.251 * *$ & $0.126^{*}$ \\
\hline & IE & 0 & 0 & 0 & 0 & 0 & 0 & 0 & 0 & 0 & 0 \\
\hline & $\mathrm{TE}$ & 0 & 0 & 0 & 0 & 0 & 0 & 1.093 & 0.380 & 0.251 & 0.126 \\
\hline \multirow{3}{*}{$\begin{array}{c}\text { Transformational } \\
\text { leadership }\end{array}$} & $\mathrm{DE}$ & 0 & 0 & $0.324 * * *$ & $0.518^{* * *}$ & $0.636^{* * *}$ & $0.425^{* * * *}$ & 0 & 0 & $0.668^{* * *}$ & $0.646^{* * * *}$ \\
\hline & IE & 0 & 0 & 0 & 0 & 0 & 0 & 0 & 0 & 0.198 & 0.053 \\
\hline & $\mathrm{TE}$ & 0 & 0 & 0.324 & 0.518 & 0.636 & 0.425 & 0 & 0 & 0.866 & 0.699 \\
\hline
\end{tabular}

Note. $* p<.05, * * p<.01, * * * p<.001$. 
Regression Equation (standardized)

$$
\begin{gathered}
\text { Group awarded TQA / TQC: BSC }=0.668 \mathrm{TLS}+0.119 \mathrm{COM}+0.251 \mathrm{EMP} \\
\qquad \mathrm{R}^{2}=0.81 \\
\text { Survival industries group: } \mathrm{BSC}=0.646 \mathrm{TLS}+0.126 \mathrm{EMP} \\
\mathrm{R}^{2}=0.56
\end{gathered}
$$

The path analysis in Table 5 illustrates the direct, indirect and total effect in model. The finding indicated that direct effect between Transformational leadership and Organization performance was highest significant impact than other variables for both groups $(\beta) 0.668$ and 0.646 . Furthermore, the finding shows that indirect effect of Transformational leadership in Group awarded TQA / TQC had quite clearly indirect impact on the Organization performance than Survival industries group due to area of $\mathrm{COM} \rightarrow \mathrm{BSC}$ non-significant influence.

\section{Findings}

As illustrated the Emotional intelligence was found to have a stronger prediction power transformational leadership in both group. $\left(\gamma=0.97, \mathrm{R}^{2}=0.94\right)$. It is noteworthy that the resulted in Table 5 , the result showed that the level mean value of causal term between Group award TQA/TQC and Survival industries group has only one factor that was not significant $(\mathrm{p}$-value $=0.364)$ in factpr of empowerment. Apart from this finding, Figure 1 structure equation model showed that the factor loading between EMP $\rightarrow$ TEF are different weight. $(\beta=1.09$ and 0.38). These result revealed that the aim of both manager group wish to distribute their authorize to subordinate but the outcome was different ( $\beta=1.09$ and 0.38 ) that mean the implement method to empowerment of Group award TQA/TQC seem more effectiveness than Survival industries group. Based on the results reported in measuring model is reflective construct indicator on a factor analysis that latent variables will influence to measured variables which measurement of these variables vary together. This relationship is called Measurement model pointed out (outer-directed measurement model), which of this nature study cutting / reducing a measure not affect to conceptual domain of the latent variables. This explains the reduction some of measure variables $(\lambda$ $<0.6)$ in both model are different on steps of confirmation factor analysis (CFA) and MI to test the consistency of model (fit index).

\section{Discussion}

The main objective of this study was to examine compare levels of behavior Transformational leadership and study causal factors of Transformational leadership between 2 groups and determine the Structural Equation Modeling between transformational leadership and causal factors as researcher developed. The finding shows that different levels of Transformational leadership in both sample groups and Group awarded TQA / TQC higher than Survival industries group. Not only of Transformational leadership level but also emotional intelligence, Organization commitment, Team effectiveness and Organization performance in both sample groups are different, which Group awarded TQA / TQC higher than Survival industries group as well. While almost entirely factors were different, the area of Empowerment is not significant. Furthermore, the finding of this study was confirmed hypothesis which stated as there is significant influence in latent variables within Structural Equation Modeling in Group awarded TQA / TQC but does not influence in some latent variables in Survival industries group. Based on this unique finding the executives in industrial sector of Thailand deal positively with organization's performance, once they have good and effective leader without forgotten the motivative factor. Thus, the leader behavior is an essential factor among Thai's industries. In this regard, transformational leadership style were enhanced the organization commitment, empowerment and organization performance factors, and it was in line with previous studies such as (Kenneth, 2006; Nontaya, 2010; Siver, 2000; Palmer et al., 2001; Geery \& Stough, 2002; Krittakorn, 2010; Phenporn, 2010) who viewed transformation leadership as having a positive influence with organization commitment, empowerment and organization performance factors. The finding of these studies also found positive influence between emotional intelligence and transformation leadership. Finally, the Survival industries group should improve or re-process in area of organization commitment with a focus on the "how to link employee commitment to organization performance" as well as other factors to increase more better organization performance.

\section{Future Research}

It is noteworthy that the result of this research may be different in other field such as finance sector or in other countries. This difference may be due to rule of each area and culture differences of each countries that interest to study for these issue. In the light of foregoing and the results obtained, it is suggested that in order to preserve stability of Transformational leadership model should be selected the managers for personality testing by standard behavior testing tools such as DISC of MBTI to identified those managers. Additionally, future studies 
may choose focus on to be able to examine the effect of transformational leadership on the postulated relationship in depth especially the survival industrial group to find out the cause of non-significant influence. Finally, future studies should be attention to explore other organization factors that could enhance to what extent external factors their effect varies cross context to study.

\section{References}

Allio, R. J. (2005). Leadership development: teaching versus learning. Management Decision, 43(7/8), 1071-1077. http://dx.doi.org/10.1108/00251740510610071

Arthi, A. (2011). Visionary leadership in Thailand and ASEAN Economic Community. Ranhsit Journal of Arts and Sciences, 1(1), 8. Retrived from http://library.rsu.ac.th/Images/journal/RJAS.pdf

Bar-On, R., \& Parker, D. A. (2000). The Handbook of Emotional Intelligence. San Francisco: Jossey-Bass.

Bass, B. M., \& Riggio, R. E. (2006). Transformational leadership (2nd ed.). Mahwah, NJ: Lawrence Erlbaum Associates.

Drucker, P. (1985). Creativity: The Discipline of Innovation. Harvard Business Review, 34(4), 39-44.

Faculty of Economics. Chulalongkorn University. (2010). The development of manpower as Thailand strengthening of government policy 2012. Retrieved February 20, 2013, From http://home.dsd.go.th/SDP/filedownload/report/ [DSD]_FinalReport.pdf

Fechter, W. F., \& Horowitz, R. B. (1991). Visionary Leadership Needed by All Managers. Industrial Management, 33(4), 13-18.

Geery, L. J., \& Stough, C. (2002). Examining the relationship between leadership and emotional intelligence in senior level manager. Leadership Organization Development Journal, 23(2), 68-78. http://dx.doi.org/10.1108/01437730210419198

Goleman, D. (2000). Leadership that gets Results. Harvard Business Review, 78(2), 78-90.

Hackman, J. R., \& Wageman, R. (2005). A Theory of Team Coaching. Academy of Management Review, 30(2), 269-287. http://dx.doi.org/10.5465/AMR.2005.16387885

Hair, J. F., Black, W. C., Babin, B. J., Anderson, R. E., \& Tatham, R. L. (2006). Multivariate data analysis (6th ed.). New Jersey: Pearson Prentice Hall.

Hitt, M. A., Ireland, R. D., \& Hoskisson, R. E. (2005). Strategic management: globalization and competitiveness. Mason, OH: Thomson South-Western.

Kaplan, R. S., \& Norton, D. P. (1996). Balanced Scorecard: Translating Strategy into Action. Boston: Harvard Business School Press.

Kenneth, E. R. (2006). Examinations of leader effect behavior within successful Fortune 100 companies. Capella University.

Krittakorn, G. (2010). Empirical Impact of Competition Rivalry, Knowledge Management, Learning Climate, Readiness to Change and Innovation on Performance of Siam Commercial Bank Branches. Ph.D. Dissertation, National Institute of Development Administration (NIDA), Thailand.

Loo, R., \& Thorpe, K. (2000). Confirmatory factor analyses of the full and short versions of the marlowe-crowne social desirability scale. The Journal of Social Psychology, 140, 628-635. http://dx.doi.org/10.1080/00224540009600503

Meyer, J. P., \& Allen, N. J. (2007). The measurement and antecedents of affective, continuance and normative commitment to the organization. Journal of Occupational Psychology, 63(1), 1-18.

Nanus, B. (1992). Visionary leadership. San Francisco: Jossey-Bass.

Nontaya, I. (2010). The administrative organization excellence of electric, electronics and part component industries. University of the Thai Chamber of Commerce Journal, 30(4), 17-29.

Office of Thailand Quality Award. (2013). Thailand Quality Award: Thailand Productivity Institute. Retrieved March 25, 2013, from http://www.tqa.or.th

Office of the National Economics and Social Development Board (NESDB). (2006). Industry sectors and services trends in Thailand. Retrieved April 25, 2013, From http://www.nesdb.go.th/portals/0/tasks/dev_ability/ Profile/industry/A2.pdf

Palmer, B., Walls, M., Burqess, Z., \& Stough, C. (2001). Emotional intelligence and effective leader. Leadership 
and Organization Development Journal, 22(1), 1-7. http://dx.doi.org/10.1108/01437730110380174

Phenporn, T. (2010). A Structure Equation Model of Transformation Leadership for Basic School Administrators. Ph.D. Dissertation, Khon Kaen University, Thailand.

Porter, M. E., \& Kramer, M. R. (2006). Strategy and Society: The Link between Competitive Advantage and Corporate Social Responsibility. Harvard Business Review, December, 78-92.

Silver, S. R. (2000). Perceptions of Empowerment in Engineer Workshops: The Linkage to Transformational Leadership and Performance. Ph.D. Dissertation, George Washington University, Washington.

Spreitzer, G. M., \& Quinn, R. E. (2001). A Company of Leaders: Five Disciplines for Unleashing the Power in Your Workforce. CA: John Wiley \& Sons.

Zaccaro, S. J., \& Banks, D. (2004). Leader visioning and adaptability: Bridging the gap between research and practice on developing the ability to manage change. Human Resource Management, 43(4), 367-380. http://dx.doi.org/10.1002/hrm.20030

\section{Copyrights}

Copyright for this article is retained by the author(s), with first publication rights granted to the journal.

This is an open-access article distributed under the terms and conditions of the Creative Commons Attribution license (http://creativecommons.org/licenses/by/3.0/). 